\title{
Factors Influencing Job Satisfaction of Nurses in Tertiary Health Care Centres in Port Harcourt, Rivers State, Nigeria
}

\author{
Udo Orukwowu* and Jane Baridah Kue
}

Department of Nursing Sciences, Faculty of Basic Medical Sciences, College of Medical Sciences, Rivers State University, Nigeria.

*Corresponding author email: udocd27@gmail.com; Phone: +2349060039098

\begin{abstract}
This study examined the factors influencing nurses satisfaction in tertiary health care centres in Port Harcourt, Rivers State. It ascertained the factors that affect nurses' satisfaction in tertiary health care centers in Port Harcourt, Rivers State. Four objectives and hypotheses were formulated to guide the study. The population of the study consisted of four hundred and twenty (420) nurses in Government-owned tertiary health care centres in Port Harcourt which was further reduced to a sample size of two hundred and five (205), using Taro Yamane's formula while Kendall tau b was implored in testing the null hypotheses. The findings revealed that a significant relationship exists between working conditions, pay/salary, professional esteem, bum out and nurses' job satisfaction in tertiary health care centers in Port Harcourt. It was concluded that if necessary steps are taken, the nurses would be more effective in their job. The recommended steps amongst others are that the working conditions of nurses should be improved, incentives and reward given for hard work, professional training and salaries paid timely as these will bring about job satisfaction among them.
\end{abstract}

Keywords: Nurses, Job satisfaction, Work environment, Tertiary health care, Working conditions
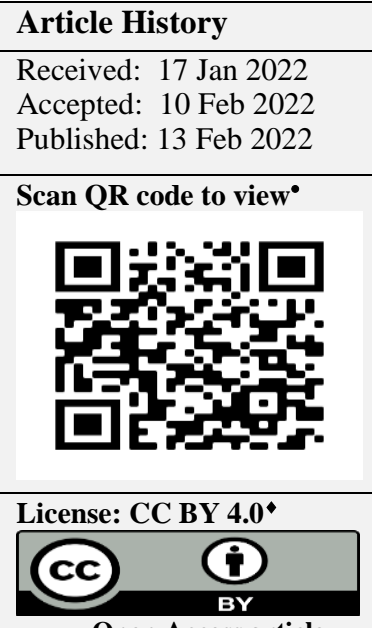

Open Access article.

How to cite this paper: Orukwowu, U. and Kue, J.B. (2022). Factors Influencing Job Satisfaction of Nurses in Tertiary Health Care Centres in Port Harcourt, Rivers State, Nigeria. IPS Journal of Management and Administration, 1(1), 1-6. https://doi.org/10.54117/ijma.v1i1.1.

\section{Introduction}

The effectiveness of a company is dependent mainly on the well-being of workers. It was talked about that work-satisfaction associated with the wellbeing of employees is very essential in gathering worker inspiration and effectiveness as greater work satisfaction define better worker efficiency and high-quantity of patients contentment (Akinwale and George, 2020). Additionally, it's been seen that after health care professionals are pleased with their work due to the existence of important components in the place of work that enhance and encourage the manpower, prices of absenteeism and return intention frequently reduce, employees well-being and productiveness enhance and work efficiency all together increases. In literary works, there are many other meanings of work satisfaction. The internet company dictionary characterized work-satisfaction as satisfaction (or deficiency of it) which emerges out of the interplay of employees good and bad emotions toward their work. Based on Greenberg \& Baron (2000), work satisfaction is dependent on the total level and unfavorable ideas of workers with respect to their workplace. It commonly describes how contented a person is by using his/her work or the emotions individuals have about their work. The major workers perspective is work satisfaction and workers have perspectives about various facets of their work, their job and for who they work.

Quality place of work on the other side was caused by nurse practitioners work satisfaction, business dedication \& most significantly, intent to stay engaged (Asegid et al., 2014; Ezeja et al., 2010). The arrangement of a favorable and high-quality workplace happens to be reported as the utmost impact that is important of contentment for nurse practitioners (Almalki et al., 2012). By thinking about the significance of nurses, discontentment along with their work will inevitably have immense communal wellness involvement bearing in mind the fact that these sets of nurse practitioners form the prominent portion of trained healthcare providers within the social group of the growing nations. However, taking into account the interplay between favorable place of work and work- satisfaction, utilization of the principal healthcare approach or of any other well-being system that intends to enhance the quality of wellness of Nigerians are faulty if appropriate and high-quality workplace and loyal and contented group are not created and positioned in their right perspective for effective service distribution (Omolase et al., 2010).

Policy developers know that the issue that is common to operate contentment and nurses' decrease is present internationally and locally (Kakande, 2010). Nurse practitioners' retention and discontentment issues, affects the decrease in nurse practitioners. Presently medical shortfall is confirmed by fewer pupils choosing nursing jobs, and by the increasing interest in nurse practitioners brought on by greater persistent ailments as well as an aging populace. The explanation for this shortfall is discontentment with compensation; advantage offers; place of work; skilled worth, determination and several other elements. However, numerous research reports have analyzed nurses work satisfaction, it continues to be ambiguous which elements are most authoritative regarding work that is high in this environment. Whereas past research is dedicated to remote affecting facets, they lacked an exploration that is complete of business facets, specially such as factors and blends of workplace and care and attention of employees wellness concurrently. For the existing research, the investigator reached on work satisfaction being a result dependent on a variety of organizational and individual facets.

This research is likely to be of great importance because: it would provide policymakers and the government with basic knowledge of what causes nurses' dissatisfaction. It is also likely to create awareness to the nurses about what 
causes dissatisfaction and how it can affect their performance. The awareness $\mathrm{N}=$ Populace size

would make it possible for proper management of stressful conditions e=Significant Level

emanating from the health care system. Therefore, the aim of this study is to Applying the formula

ascertain the factors that affect nurse's satisfaction in tertiary health care centers in Port Harcourt. The specific objectives are to:

$n=\frac{420}{1+420(0.05)^{2}}$
$n=\frac{420}{1+420(0.0025)}$

- Ascertain the relationship between working conditions and job satisfaction of nurses in tertiary health institutions.

- Ascertain the relationship between pay/salary and job satisfaction of nurses in tertiary health institutions.

- Ascertain the relationship between professional esteem and job satisfaction of nurses in tertiary health institutions.

- Ascertain the relationship between burnout and job satisfaction of nurses in tertiary health institutions.

The findings of this research will also add to the existing knowledge already piled up in this area of study. Students, researchers and authors who may wish to carry out further studies in this topic or related areas will find this study useful as it will serve as good reference material.

\section{Methodology}

\subsection{Research Design}

Research design is seen as a model that practically directs the research worker within the different phases of this research. Put it in another way, it is a structure that prepared strategy in research, developed to be able to get responses to study concerns as validly, rationally, precisely and fiscally as possible. There are two main kinds of research design; empirical and Quasi-empirical research design. The investigation design used by the researcher is the Quasi-empirical research design. The reason is that the components under research (people) are versatile, and therefore are not managed by the researcher. Although this technique will be applied, the cross-sectional study is likewise used since the study uses a sample of components through the populace of great focus which will be calculated at a single point.

\subsubsection{Research Hypothesis for the Study}

The following questions will be answered by this investigation:

$\mathbf{H O}_{1}$ : There is no significant relationship between working conditions and nurses' work satisfaction in tertiary health care centers in Port Harcourt.

$\mathbf{H O}_{2}$ : There is no significant relationship between pay/salary and nurses' work satisfaction in tertiary health care centers in Port Harcourt.

$\mathrm{HO}_{3}$ : There is no significant relationship between professional esteem and nurses' work satisfaction in tertiary health care centers in Port Harcourt.

$\mathrm{HO}_{4}$ : There is no significant relationship between burnout and nurses' work satisfaction in tertiary health care centers in Port Harcourt.

\subsection{Populace Distribution of the Study}

The populace as a census of all items or subjects that contain the characteristics of which have the data associated with the event being analyzed. Thus, the populace of this scholarly research was pulled out from the nurse practitioners within the tertiary medical facilities in Port Harcourt. Our accessible populace had been further gotten by way of a judgmental sample process. Based on the ministry of health, Rivers state section, the true quantity of nurses in Governmental tertiary medical centers is four hundred and twenty (420) (Table 1).

Table 1: Population Distribution of the Study

\begin{tabular}{|c|c|c|}
\hline$\overline{S / N}$ & Respondents & Number \\
\hline 1 & Nursing Officer & 88 \\
\hline 2 & Senior Nursing Officer & 100 \\
\hline 3 & Assistant chief Nursing Officer & 195 \\
\hline 4 & Chief Nursing Officer & 37 \\
\hline Total & & 120 \\
\hline
\end{tabular}

\subsection{Sample and Sampling Technique}

Taro Yamane's (1967) sample-size determination procedure was utilized to look for the sample size suitable for this study. The formulae is as follows: $n=\frac{N}{1+N(e)^{2}}$

$\mathrm{n}=$ Sample size

$n=\frac{420}{2.05}$

$\mathrm{n}=205$

Consequently, a sample size of 205 had been utilized in the research.

Sample methods are extensively grouped as probability or non-probability sample methods. The probability sample methods offer every aspect in the known populace and possibility that is equally chosen through the test. Whilst the non-probabilistic sample methods offers room for prejudice while the implementation of experience and insights that are naturally driven and certainly will cause an error.

Hence, having reached a sample that is appropriate of 205, a probabilistic simple random sampling was utilized in picking the 205 participants.

\subsection{Nature and Source of Data}

This research obtained its information or data from a primary source by adapting the survey questionnaire developed by the researcher.

\subsection{Validity and Reliability of Instrument}

Validity

Validity is identified as the standard of information or data collecting tool or process that makes it possible for it to assess efficiently and accurately what it's expected to determine. Consequently, to be able to determine the internal, external, content and construct validity in this research, the supervisor and other lecturers in the department of management, analyzed the survey questionnaire tool and made suggestions and critics after which necessary modifications had been made based on the suggestions.

\section{Reliability}

The reliability of the questionnaire was ascertained with the use of the testretest reliability technique. The instruments were administered to 30 respondents not involved in the sample of the study. After two weeks the test was carried out again on the same respondents. The findings were correlated using the Cronbach alpha correlation coefficient, which was used to ascertain the consistency of the instruments. It yielded a correlation coefficient index value of 0.86 .

\subsection{Operational Measure of Variable}

Our measurement tool in this study was our organized survey questionnaire, as shown in Appendix 1.

Our predictor variable in this research is "working condition, pay/salary, professional esteem and burnout", (17 items) in all would be utilized in evaluating this variable.

The criterion variables in this research are "work satisfaction". (5items) in all would be utilized in evaluating this variable.

The responses to each of the items were scaled using a 5-point Likert scale: ranging from $(5=$ Strongly agree, to $1=$ Strongly disagree $)$.

\subsection{Data Analysis Techniques}

This study employed the use of frequency and percentages in answering research questions, while Kendall's Tau-b correlation coefficient was used in testing the hypotheses formulated for the study, at a 0.05 level of significance. This method was used for this research since it is more reliable in ensuring whether two data that are non-parametric with ties are associated. Also, it really is used in examining data that are ordinal. The data gathered was according to the ordinal scale. (SPSS; Statistical package for social science version 20.0) ended up being used in evaluating the data. The program has actually the propensity of evaluating both descriptive and inferential data.

\section{Results}

\subsection{Data Presentation}

A total of two hundred and five (205) copies of questionnaire were distributed to nurses in the tertiary health centers in Port Harcourt. Out of these, one hundred and ninety (190) copies were returned (Table 2). This 
represent $92.69 \%$ rate of return. All returned questionnaire was properly filled.

Table 2: Questionnaire response rate

\begin{tabular}{|c|c|c|c|c|}
\hline S/No & HealthCenters & $\begin{array}{l}\text { Number } \\
\text { Given }\end{array}$ & $\begin{array}{l}\text { Number } \\
\text { Retrieved }\end{array}$ & $\begin{array}{l}\text { Number not } \\
\text { Retrieved }\end{array}$ \\
\hline$T$ & Nursing Officer & 70 & 65 & 5 \\
\hline 2 & Seniar Nursing Officer & 60 & 57 & 3 \\
\hline 3 & Assistant chiefNursing Officer & 40 & 35 & 5 \\
\hline 4 & Chief Nursing Officer & 35 & 33 & 12 \\
\hline & Total & 205 & 190 & 15 \\
\hline
\end{tabular}

\subsection{Demographic Data Analysis and Results}

The table showed, 45(23.7\%) of the respondents were between 20-29 years of age, $60(31.6 \%)$ of them were between $30-39$ years, $45(23.7 \%)$ of them were between $40-49$ years, while $40(21.1 \%$ ) were 50 years and above (Table 3).

Table 3: Distribution of respondents by age group.

\begin{tabular}{|c|c|c|}
\hline & Frequency & Percent \\
\hline 20-29 YEARS & 45 & 23.7 \\
\hline 30-39 YEARS & 60 & 31.6 \\
\hline 40-49 YEARS & 45 & 23.7 \\
\hline $\begin{array}{l}50 \text { YEARS AND } \\
\text { ABOVE }\end{array}$ & 40 & 21.1 \\
\hline Total & 190 & 100.0 \\
\hline
\end{tabular}

It was found that $45(23.7 \%)$ of the respondents were male, while $145(76.3 \%)$ of the respondents were females (Table 4 ).

Table 4: Distribution of respondents by gender group.

\begin{tabular}{|l|r|r|}
\hline & Frequency & Percent \\
\hline MALE & 45 & 23.7 \\
FEMALLE & & 145 \\
Total & 190 & 76.3 \\
\hline
\end{tabular}

Table 5 Showed that $40(21.1 \%)$ of the respondents were single, $135(71.1 \%)$ of them were married, while $15(7.9 \%)$ of the respondents were others.

Table 5: Distribution of respondent by marital status.

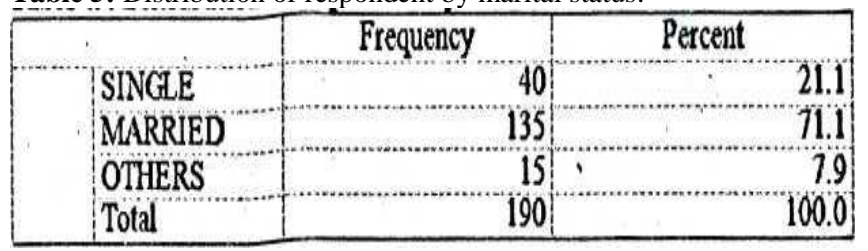

Table 6 showed that $140(73.7 \%)$ of the respondents were Christians, $40(21.1 \%)$ of them were Muslims, while $10(5.3 \%)$ of the respondents belongs to other religion.

Table 6: Distribution of respondents by Religious group

\begin{tabular}{|l|r|r|}
\hline CHRISTAINI & Frequency & Percent \\
TY & 140 & 73.7 \\
MUSLIM & 40 & 21.1 \\
OTHERS & 10 & 5.3 \\
Total & 190 & 100.0 \\
\hline
\end{tabular}

Table 7 showed that $65(34.2 \%)$ of the respondents had MSc/MNSc/ as their highest level of education, $85(44.7 \%)$ of them had B.Sc/B.NSc,
$31(16.3 \%)$ of them had HND certificate in nursing, while $9(4.7 \%)$ had OND degree as their highest level of education.

Table 7: Distribution of respondents by Level of Education

\begin{tabular}{|l|r|r|}
\hline MScMNSc & Frequency & Percent \\
BScBNSc & 65 & 34.2 \\
HND CERTIFICATE & 85 & 44.7 \\
INNURSING & 31 & 16.3 \\
OND & 9 & 4.7 \\
Total & 190 & 100.0 \\
\hline
\end{tabular}

Table 8 showed that $65(34.2 \%)$ of the respondents were nursing officers, $57(30 \%)$ of them were senior nursing officers, $35(18.4 \%)$ of them were assistant chief nursing officers, while $33(17.4 \%)$ of the respondents were chief nursing officers.

Table 8: Distribution of respondents on present professional status

\begin{tabular}{l|r|r|}
\hline & \multicolumn{1}{|c|}{ Frequency } & Percent \\
\hline $\begin{array}{l}\text { NURSING OFFICER } \\
\text { SENIOR NURSING } \\
\text { OFFICER } \\
\text { ASST.CHIEF }\end{array}$ & 65 & 34.2 \\
$\begin{array}{l}\text { NURSINGOFFICER } \\
\text { CHIEF NURSING }\end{array}$ & 57 & 30.0 \\
OFFICER & 35 & 18.4 \\
Total & 33 & 17.4 \\
\hline
\end{tabular}

\subsection{Response to Questionnaire}

Base on Table 9, item one revealed that, 110(57.89\%) of our respondents stated strongly-agreed, $50(26.32 \%)$ of them stated agreed, whereas $30(15.79 \%)$ of them stated disagreed. For item two, $105(55.26 \%)$ of our respondents stated strongly-agreed, $60(31.59 \%)$ of them stated agreed, whereas $25(13.16 \%)$ of them stated disagreed. For item three, $110(57.89 \%)$ of our respondents stated strongly-agreed, $50(26.32 \%)$ of them stated agreed, whereas $30(15.79 \%)$ of them stated stronglydisagreed. For item four, 100(52.63\%) of our respondents stated stronglyagreed, $70(36.84 \%)$ of them stated agreed, whereas $20(10.53 \%)$ of them stated disagreed. For item five, $120(63.16 \%)$ of our respondents stated strongly-agreed, $50(26.32 \%)$ of them stated agreed, whereas $20(10.53 \%)$ of them stated disagreed.

Table 9: Response on Professional Esteem

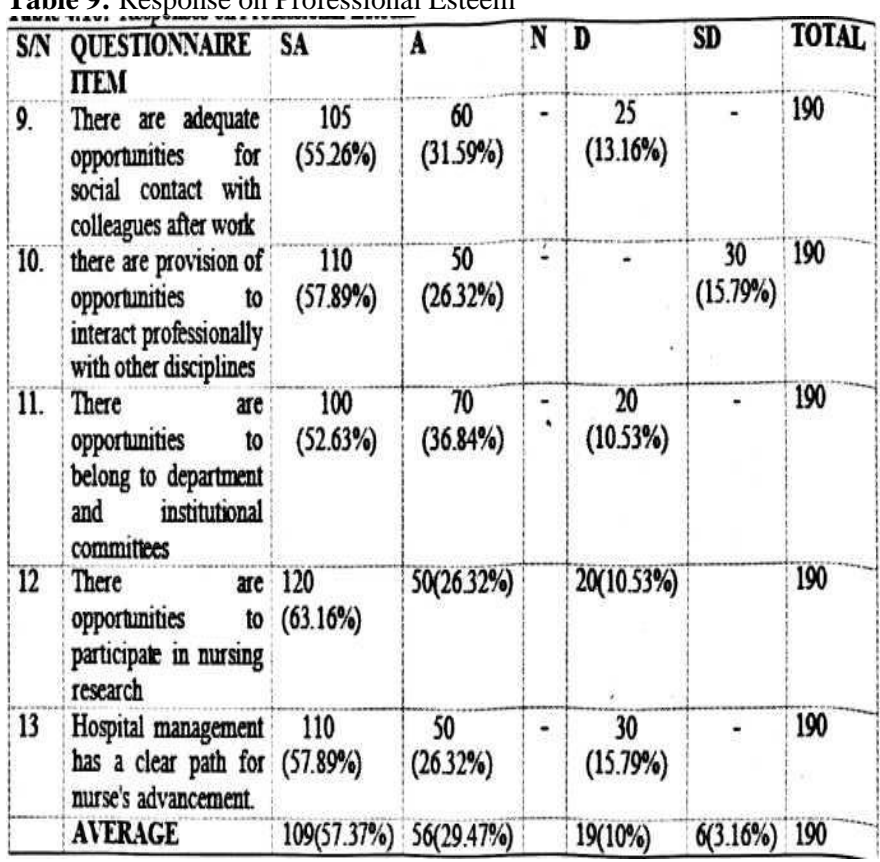

$\mathrm{SA}=$ Strongly agreed; $\mathrm{A}=$ Agreed; $\mathrm{D}=$ Disagree; $\mathrm{SD}=$ Strongly disagree 
Base on Table 10, item six revealed that, $90(47.37 \%)$ of our respondents stated strongly-agreed, $70(36.84 \%)$ of them stated agreed, whereas $30(15.79 \%)$ of them stated disagreed. For item seven, $90(47.37 \%)$ of our respondents stated strongly-agreed, $70(36.84 \%)$ of them stated agreed, whereas $30(15.79 \%)$ of them stated to disagreed. For item eight, $100(52.63 \%)$ of our respondents stated strongly-agreed, $65(34.21 \%)$ of them stated to agreed, whereas $25(13.16 \%)$ of them stated disagreed.

Base on the above table, item nine revealed that, 105(55.26\%) of our respondents stated strongly-agreed, $60(31.59 \%)$ of them stated agreed, whereas $25(13.16 \%)$ of them stated disagreed. For item ten, 110(57.89\%) of our respondents stated strongly-agreed, $50(26.32 \%)$ of them stated agreed, whereas $30(15.79 \%)$ of them stated strongly- disagreed. For item eleven, $100(52.63 \%)$ of our respondents stated strongly-agreed, $70(36.84 \%)$ of them stated agreed, whereas $20(10.53 \%)$ of them stated disagreed. For item twelve, $120(63.16 \%)$ of our respondents stated strongly-agreed, $50(26.32 \%)$ of them stated agreed, whereas $20(10.53 \%)$ of them stated disagreed. For item thirteen, 110(57.89\%) of our respondents stated strongly-agreed, $50(26.32 \%)$ of them stated agreed, whereas $30(15.79 \%)$ of them stated disagreed.

Table 10: Responses on Burnout

\begin{tabular}{|c|c|c|c|c|c|c|c|}
\hline S/N & $\begin{array}{l}\text { QUESTIONNAIRE } \\
\text { IIEM }\end{array}$ & $S A$ & A & $\mathrm{N}$ & D & SD & TOTAL \\
\hline 14. & $\begin{array}{l}\text { Conflict and lack of } \\
\text { recognition usually } \\
\text { make me dissatisfied }\end{array}$ & $\begin{array}{c}115 \\
(60.53 \%)\end{array}$ & $\begin{array}{c}65 \\
(3421 \%)\end{array}$ & $\cdot$ & $\begin{array}{c}10 \\
(5.26 \%)\end{array}$ & - & 190 \\
\hline 15. & $\begin{array}{l}\text { work overload is a } \\
\text { major cause of stress to } \\
\text { me }\end{array}$ & $\begin{array}{l}95 \\
(50 \%)\end{array}$ & $\begin{array}{c}70 \\
(36.84 \%)\end{array}$ & $\therefore$ & $\begin{array}{c}25 \\
(13.16 \%)\end{array}$ & ? & 190 \\
\hline 16. & $\begin{array}{l}\text { Difficulty in dealing } \\
\text { with aggressive } \\
\text { patients is a major } \\
\text { indicator of bumout }\end{array}$ & $\begin{array}{c}100 \\
(52.63 \%)\end{array}$ & $\begin{array}{c}65 \\
(3421 \%)\end{array}$ & $\cdot$ & $\begin{array}{c}25 \\
(13.16 \%)\end{array}$ & $\cdot$ & 190 \\
\hline 17 & $\begin{array}{l}\text { I sometimes feel my } \\
\text { wotk is meaningless. }\end{array}$ & $\begin{array}{l}95 \\
(50 \%)\end{array}$ & $\begin{array}{c}70 \\
(36.84 \%)\end{array}$ & $\cdot$ & $\begin{array}{c}25 \\
(13.16 \%)\end{array}$ &  & 190 \\
\hline & AVERAGE & $101(53.16 \%)$ & $68(35.79 \%)$ & & $21(11.05 \%)$ & & 190 \\
\hline
\end{tabular}

$\mathrm{SA}=$ Strongly agreed; $\mathrm{A}=$ Agreed $\mathrm{D}=$ Disagree $\mathrm{SD}=$ Strongly disagree

Base on the above table, item fourteen revealed that, 115(60.53\%) of our respondents stated strongly-agreed, $65(34.21 \%)$ of them stated agreed, whereas $10(5.26 \%)$ of them stated disagreed. For item fifteen, $95(50 \%)$ of our respondents stated strongly-agreed, 70(36.84\%) of them stated agreed, whereas $25(13.16 \%)$ of them stated disagreed. For item sixteen, $100(52.63 \%)$ of our respondents stated strongly-agreed, $65(34.21 \%)$ of them stated agreed, whereas $25(13.16 \%)$ of them stated disagreed. For item seventeen, $95(50 \%)$ of our respondents stated strongly-agreed, $70(36.84 \%)$ of them stated agreed, whereas $25(13.16 \%)$ of them stated disagreed.

In Table 11, item eighteen revealed that, 105(55.26\%) of our respondents stated strongly-agreed, $60(31.59 \%)$ of them stated agreed, whereas $25(13.16 \%)$ of them stated disagreed. For item nineteen, $110(57.89 \%)$ of our respondents stated strongly-agreed, $50(26.32 \%)$ of them stated agreed, whereas $30(15.79 \%)$ of them stated strongly-disagreed. For item twenty, $100(52.63 \%)$ of our respondents stated strongly- agreed, $70(36.84 \%)$ of them stated agreed, whereas $20(10.53 \%)$ of them stated disagreed. For item twenty-one, $120(63.16 \%)$ of our respondents stated strongly- agreed, $50(26.32 \%)$ of them stated agreed, whereas $20(10.53 \%)$ of them stated disagreed. For item twenty-two, 110(57.89\%) of our respondents stated strongly-agreed, 50(26.32\%) of them stated agreed, whereas 30(15.79\%) of them stated disagreed.

\subsection{Statistical Test of Hypotheses}

The hypotheses of this work was analyzed statistically using Kendall tau$\mathrm{b}$ at a 0.05 significant degree (Tables 12-15).

$\mathrm{HO}_{1}$ : There is no significant correlation between working condition and nurses' work satisfaction in tertiary health care centers in Port Harcourt (Table 12).
Table 11: Responses on work satisfaction

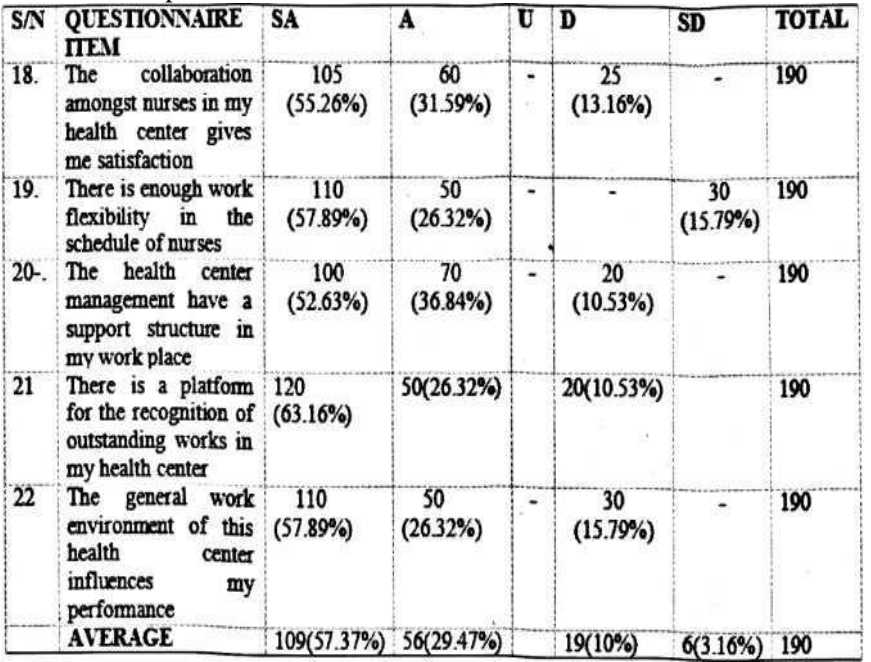

$\mathrm{SA}=$ Strongly agreed; $\mathrm{A}=$ Agreed $\mathrm{D}=$ Disagree; $\mathrm{SD}=$ Strongly disagree

Table 12: Kendall's tau_b Tests Output $\mathrm{HO}_{1}$

Correlations

\begin{tabular}{|c|c|c|c|c|}
\hline & & & $\begin{array}{c}\text { Working } \\
\text { Condition }\end{array}$ & $\begin{array}{c}\text { work } \\
\text { Satisfaction }\end{array}$ \\
\hline \multirow{6}{*}{$\begin{array}{l}\text { Kendall's } \\
\text { tau_b }\end{array}$} & \multirow{3}{*}{ Working Condition } & $\begin{array}{l}\text { Correlation } \\
\text { Coefficient }\end{array}$ & 1.000 & $.227^{*}$ \\
\hline & & Sig. (2-tailed) & 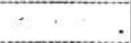 & .000 \\
\hline & & N & 190 & 190 \\
\hline & \multirow{3}{*}{ work Satisfaction } & $\begin{array}{l}\text { Correlation } \\
\text { Coefficient }\end{array}$ & $.72 T^{*}$ & 1.000 \\
\hline & & Sig. (2-biled) & .000 & \\
\hline & & $\mathrm{N}$ & 190 & 190 \\
\hline
\end{tabular}

**. Correlation is significant at the 0.05 level (2-tailed).

Base on the outcome, the above table shows that correlation coefficient ( $\mathrm{r}$ $=0.727$ ) between working condition and work satisfaction is strong and positive. Also, our value of significance $0.000(\mathrm{p}<0.05)$ discloses a substantial correlation. With regards to the above, our null-hypothesis is turned down and the alternate be accepted. Thus, there is a significant correlation between working condition and nurses' work satisfaction in tertiary health care centers in Port Harcourt.

$\mathrm{HO}_{2}$ : There is no significant correlation between pay/salary and nurses' work satisfaction in tertiary health care centers in Port Harcourt (Table 13).

Table 13: Kendall's tau_b Tests Output $\mathrm{HO}_{2}$

\begin{tabular}{|c|c|c|c|c|}
\hline & & & Pay/Salary & $\begin{array}{c}\text { work } \\
\text { Satisfaction }\end{array}$ \\
\hline \multirow{6}{*}{$\begin{array}{l}\text { Kendall's } \\
\text { tau_b }\end{array}$} & \multirow{3}{*}{ Pay/Salary } & $\begin{array}{l}\text { Correlation } \\
\text { Coefficient }\end{array}$ & 1.000 & $.882^{* *}$ \\
\hline & & Sig. (2-tailed) & & .000 \\
\hline & & $\mathrm{N}$ & 190 & 190 \\
\hline & \multirow{3}{*}{ work Satisfaction } & $\begin{array}{l}\text { Correlation } \\
\text { Coefficient }\end{array}$ & $.882^{\circ+}$ & 1.000 \\
\hline & & Sig. (2-tailed) & .000 & \\
\hline & & $\mathrm{N}$ & 190 & 190 \\
\hline
\end{tabular}

**. Correlation is significant at the 0.05 level (2-tailed).

Based on the outcome, the above table shows that correlation coefficient $(\mathrm{r}=0.882)$ between pay/salary and work satisfaction is strong and positive. Also, our value of significance $0.000(p<0.05)$ discloses a substantial correlation. With regards to the above, our null-hypothesis is turned down and the alternate be accepted. Thus, there is a significant correlation between pay/salary and nurses' work satisfaction in tertiary health care centers in Port Harcourt. 
$\mathrm{HO}_{3}$ : There is no significant correlation between professional esteem and nurses' work satisfaction in tertiary health care centers in Port Harcourt (Table 14).

Table 14: Kendall's tau b Tests Output $\mathrm{HO}_{3}$

Correlations

\begin{tabular}{|c|c|c|c|c|}
\hline & & & \begin{tabular}{|c|} 
Professional \\
Esteem
\end{tabular} & $\begin{array}{c}\text { work } \\
\text { Satisfaction }\end{array}$ \\
\hline \multirow{6}{*}{$\begin{array}{l}\text { Kendall's } \\
\text { tau_b }\end{array}$} & \multirow{3}{*}{ Professional Esteem } & $\begin{array}{l}\text { Correlation } \\
\text { Coefficient }\end{array}$ & 1.000 & $.812^{* *}$ \\
\hline & & Sig. (2-tailed) & & .000 \\
\hline & & $\mathrm{N}$ & 190 & 190 \\
\hline & \multirow{3}{*}{ work Satisfaction } & $\begin{array}{l}\text { Correlation } \\
\text { Coefficient }\end{array}$ & $.812^{*}$ & 1.000 \\
\hline & & Sig. (2-tailed) & .000 & \\
\hline & & $\mathrm{N}$ & 190 & 190 \\
\hline
\end{tabular}

Based on the outcome, the above table shows that the correlation coefficient $(r=0.812)$ between work satisfaction and professional esteem is strong and positive. Also, our value of significance $0.000(p<0.05)$ discloses a substantial correlation. With regards to the above, our null hypothesis is turned down and the alternate be accepted. Thus, there is a significant correlation between professional esteem and nurses' work satisfaction in tertiary health care centers in Port Harcourt.

$\mathrm{HO}_{4}$ : There is no significant correlation between burnout and nurses' Work satisfaction in tertiary health care centers in Port Harcourt (Table 15)

Table 15: Kendall's tau_b Tests Output $\mathrm{HO}_{4}$ Correlations

\begin{tabular}{|c|c|c|c|c|}
\hline & & & Burnout & $\begin{array}{c}\text { work } \\
\text { Satisfaction }\end{array}$ \\
\hline \multirow{6}{*}{$\begin{array}{l}\text { Kendall's } \\
\text { tau_b }\end{array}$} & \multirow{3}{*}{ Burnout } & $\begin{array}{l}\text { Correlation } \\
\text { Coefficient }\end{array}$ & 1.000 & $-.886^{*}$ \\
\hline & & Sig. (2-tailed) & & .000 \\
\hline & & $\mathrm{N}$ & 190 & 190 \\
\hline & \multirow{3}{*}{ work Satisfaction } & $\begin{array}{l}\text { Correlation } \\
\text { Coefficient }\end{array}$ & $-.886^{\circ}$ & 1.000 \\
\hline & & Sig.(2-tailed). & .000 & \\
\hline & & $\mathrm{N}$ & 190 & 190 \\
\hline
\end{tabular}

Based on the outcome, the above table shows that the correlation coefficient $(r=-0.886)$ between burnout and work satisfaction is strong and negative. Also, our value of significance $0.000(p<0.05)$ discloses a substantial correlation. With regards to the above, our null hypothesis is turned down and the alternate is accepted. Thus, there is a significant correlation between burnout and nurses' work satisfaction in tertiary health care centers in Port Harcourt.

\section{Discussion}

This study showed a significant relationship between working conditions and nurses' work satisfaction in tertiary health care centers. The reason for this may be because of the health centers have modem equipment, makes adequate provision of social amenities such as portable water, electricity, promotes standard and safe workplace, adequate medical facilities are provided in the health center and proper attention is paid to nurses when they are at their duty. The significant relationship that exists between pay/salary and nurses' work satisfaction in tertiary health care centers was probably due to the fact that there is usually prompt payment of salary, regular in salary, adequate benefits package (insurance, retirement) are provided for nurses, collaboration amongst nurses in their health center gives them satisfaction and the general work environment of the center influences their performance. According to Danish and Usman (2010) fringe benefits includes; benefit, and promotions as well as incentives, to a large extent, providing satisfaction to employees. Both rewards and recognition, including salary lead to higher levels of motivation and research, has shown that motivation influences satisfaction and performance. Seo et al. (2004) found seven significant factors that influence work satisfaction: positive effect, supervisory support, salary, work routines, negative effect, heavy workload and work opportunity. Payment and supervisor support had positive .effect on work satisfaction whereas routinization and workload have a negative impact on it. This interestingly implies that when salaries are regularly paid, incentives are given to hardworking employees as a reward, which will increase work satisfaction. Several authors have reported this fact, which makes this present study similar to (Danish and Usman, 2010). Furthermore, this study revealed a significant relationship between professional esteem and nurses' work satisfaction in tertiary health care centers. This may be because there are adequate opportunities for social contact with colleagues after work, there are provisions of opportunities to interact professionally with other disciplines, opportunities to belong to the department and institutional committees, opportunities to participate in nursing research and hospital management has a clear path for nurse's advancement. Many authors have argued that work training is an important predictor of employee positive attitudes (Schmidt, 2007). Work satisfaction is also found to positively impact nurses' assessments of the quality of care. Clarity of professional role has also been shown to predict work satisfaction. Therefore, it is important for nurses to be able to tell the difference between needs for role and needs for self (Beebe and Frisch, 2009). From the findings, professional esteem was seen to significantly influence nurses' work satisfaction, which was validated by several authors. This implies that the more training nurses get, the better their performance and the more satisfied they become. Therefore, this deduction agrees with the present study.

The findings also revealed a significant negative relationship between burnout and nurses' work satisfaction in tertiary health care centers. This was validated by the fact that conflict and lack of recognition usually make them dissatisfied; also, difficulty in dealing with aggressive patients is a major indicator of burnout while work overload is a major cause of stress to them. Outcomes proposed to be as a result of improved nurse work satisfaction included reduced turnover (AbuAlRub et al., 2009), decreased burnout (Abushaikha \& SacaHazboun, 2009), and decreased costs associated with orienting new nurses secondary to high turnover (Anderson et al., 2009). Lambert (2008) found that the most commonly cited workplace stressor was the workload. Aiken et al. (2002) relate high patient-to-nurse ratios to high levels of burnout and reduced satisfaction. Moradi et al. (2014) identified work overload, rotating shifts and conflict in interpersonal relationships as the most common reasons behind nurses' burnout and turnover intentions. Furthermore, Fang (2001) demonstrated that work satisfaction was positively correlated with organizational commitment, professional commitment and manager satisfaction and negatively linked to work stress, recognition, and turnover. All this literature are pointing to the negative relationship that exists between burnout and work satisfaction. This implies that the more the burnout, which includes work stress, the less satisfied the nurses become. Therefore, this agrees with the present study.

\section{Conclusion and Recommendation}

Work satisfaction of nurses in tertiary health centres in Port Harcourt was examined. The study revealed that all the four null hypotheses formulated were rejected. The extent to which working conditions, pay/salary; professional esteem and burnout influences nurses' work satisfaction in tertiary health centres is high and shows a positive linear relationship. This implies that there is a substantial correlation exists between; (i) Working conditions and nurses' work satisfaction (ii) Pay/salary and nurses' work satisfaction (iii) Professional esteem and nurses' work satisfaction and (iv) Burnout and nurses' work satisfaction.

Based on this study, the following are recommended;

- The working conditions of nurses especially, tertiary health centers should be improved by making the environment conducive, as well as providing needed facilities. As these will bring about work satisfaction among them.

- Salaries of nurses should be paid regularly and on time. Also, other incentives such as rewards for hard work should be available, in order to enhance work satisfaction.

- Nurses should be encouraged to go for more professional training that can enhance their skills and performance. As such, they will know the easier way of going about their duties, which eventually can lead to work satisfaction.

- Burnout should be minimized. This can be achieved by assigning increasing the number of workforces who can handle a specific task, thereby leading to work satisfaction. 


\section{References}

AbuAlRub, R. F., Omari, F. H., \& Al, I. M. -Z. (2009). Support, satisfaction and retention among Jordanian nurses in private and public hospitals. International Nursing Review, 56(3), 326-332. doi: 10.1111/j.14667657.2009.00718.x.

Akinwale, O.E. and George, O.J. (2020). Work environment and job satisfaction among nurses in government tertiary hospitals in Nigeria", Rajagiri Management Journal, 14(1): 71-92. https://doi.org/10.1108/RAMJ-01-2020-0002.

Asegid, A., Belachew, T., Yimam, E. (2014). Factors Influencing Job Satisfaction and Anticipated Turnover among Nurses in Sidama Zone Public Health Facilities, South Ethiopia, Nursing Research and Practice, vol. 2014, Article ID 909768, 26 pages, 2014. https://doi.org/10.1155/2014/909768.

Abushaikha, L. \& Saca, H. -H. (2009). Job satisfaction and burnout among Palestinian nurses. Eastern Mediterranean Health Journal, 15(1), 190197. Retrieved from https://www.ncbi.nlm.nih.gov/pubmed/19469443

Almalki, M. J, Fitzgerald, G \& Michele C (2012), Quality of work life among primary health care nurses in the Jazan region, Saudi Arabia: a crosssectional study. Human Resources for Health20l2.Doi: https://doi.org/10.1186/1478-4491-10- 30

Anderson, T., Linden, L Allen, M \& Gibbs, E2009.New graduate RN work satisfaction after completing an interactive nurse residency. US National Library of Medicine Apr, 39(4): 165-9. Retrieved from: https://www.ncbi.nlm.nih.gov/pubmed/19359887

Beebe, R., \& Frisch, N. (2009). Development of the Differentiation of Self and Role Inventory for Nurses (DSRI-RN): a tool to measure internal dimensions of workplace stress. Nursing Outlook, 57(5), 240-245. doi: https://doi.org/0.1016/outlook.2009.04.001

Danish, R. Q., \& Usman, A. (2010). Impact of reward and recognition on job satisfaction and motivation: An empirical study from Pakistan. International Journal of Business and Management, 5(2), 159167.doi:10.5539/ijbm.v5n2p159.
Ezeja, M.I., Anaga, A.O. (2010). Anti-diarrheal activities of the methanolic root bark extract of Cochlospermumplanchonii (Hook f). International Journal of Toxicological and Pharmacological Research, 2: 40-45.

Fang, Y (2001). Turnover propensity and its causes among Singapore nurses: an empirical study. International Journal of Human Resource Management, 12 (5) pp 859-871,

Greenberg, J. \& Baron, R. A. (2000), Behavior in Organizations, Seventh Edition, NJ: Prentice Hall. Hartman, C. C. (2000). Organizational Commitment: Method Scale Analysis and Test of Effects. International Journal of Organizational Analysis, 8, 89-109. Retrieved from: https://books.google.com.ng/books/about/Behavior_in_Organizations.htm 1?id=4LFZAAAAYAAJ\&redir_esc $=y$

Kakande.Y, (2010). Patients suffer as hospital staffs leave. The National [Online] 19 March. Retrieved from: http://www.thenational.ae/news/uaenews/health/patients-suffer-ashospital- staff-leave.

Lambert, V.N (2008).Job satisfaction among intensive care nurses from the People's Republic of China. International Nursing Review (5) pp 34 39.doi: https://doi.Org/10.1111/j.1 466-7657.2007.00573.x.

Moradi, S., Farahnaki, Z., Akbarzadeh, A., Gharagozlou, F., Pournajaf, A., Abbasi, A., Omidi, L., Hami, M., Karchani, M. (2014). Relationship between Shift Work and Job Satisfaction among Nurses: a Crosssectional Study. International Journal of Hospital Research, 3(2), 63-68.

Omolase, C. O, Seidu, M. A, Omolase, B. O \& Agborubere, D. E (2010) Job satisfaction amongst Nigerian ophthalmologists: an exploratory study. Libyan Journal ofMedicinepg 2:80-4. doi https://doi.org/10.3402/lim.v5i0.4629.

Schmidt, S. (2007). The relationship between satisfaction and workplace, training and overall job satisfaction. Human Resource Development Quarterly, 18(4), 481- 491. doi: 10.1002/hrdq.1216

Seo, Y., Ko, J. \& Price, J., (2004). The determinants of job satisfaction among hospital nurses: model estimation in Korea. International Journal of Nursing Studies, 41(4) pp. 437-446. doi: 10.1016/j.ijnurstu.2003.11.003.

- Thank you for publishing with us. 